\title{
PENGARUH PEMBEBANAN TERHADAP ARUS MOTOR EG-530AD-2F
}

\author{
Zaenal Arifin ${ }^{1}$, Franssisco Nur Candra Negara ${ }^{2}$, Muhammad Wafy ${ }^{3}$ \\ Universitas Islam Nahdlatul Ulama Jepara, \\ zenal arif21@yahoo.com, zaenalarifin elektro@unisnu.ac.id,
}

\begin{abstract}
All processes that work must be controlled by a system that can be controlled with the aim of increasing efficiency and minimizing the risk of errors. Likewise the production process with a system that can be controlled, in this case in the process of separating goods based on certain criteria as needed with PLC as the basis of control will make a combination of a complex and interrelated system to improve the performance of the system. Analysis of loading prototype of a separator system based on PLC-based altitude, with a power supply voltage of 12 Volt DC to run a prototype system, it was found that the load that can be passed on each data conveyor loading on 12volt dc motor conveyor performance eg-530ad$2 f$ is a load starting from 10-120 gr where the drive used is a 12 Volt DC motor with coupled by a $5 \mathrm{~mm}$ elastic rubber van, with overall required current of $2.15 \mathrm{~A}$, the required voltage is $12 \mathrm{Vdc} \pm 8.99 \%$.
\end{abstract}

Keywords: dc motor, load, current

\begin{abstract}
Abstrak
Semua proses yang bekerja harus terkontrol oleh suatu sistem yang dapat dikontrol dengan tujuan meningkatkan efisiensi dan memperkecil resiko error. Begitu juga proses produksi dengan sistem yang dapat dikontrol, dalam hal ini pada proses pemisahan barang yang didasarkan pada kriteria tertentu sesuai yang dibutuhkan dengan PLC sebagai basis kontrol akan menjadikan gabungan suatu sistem yang komplek dan saling berkaitan untuk meningkatkan kinerja dari sistem. Analisis pembebanan prototipe sistem pemisah barang berdasarkan ketinggian berbasis PLC ini, dengan tegangan power supply sebesar 12 Volt DC untuk menjalankan sistem prototipe, didapatkan bahwa beban yang mampu dilewatkan pada masing-masing konveyor data pembebanan terhadap unjuk kerja konveyor motor dc $12 \mathrm{volt}$ eg-530ad-2f adalah beban mulai dari $10-120 \mathrm{gr}$ dimana penggerak yang digunakan adalah motor DC 12 Volt dengan dikopel oleh van-belt karet elastis $5 \mathrm{~mm}$, dengan arus yang dibutuhkan secara keseluruhan $2.15 \mathrm{~A}$, tegangan yang dibutuhkan adalah sebesar $12 \mathrm{Vdc} \pm 8.99 \%$.
\end{abstract}

Kata kunci : motor dc, beban, arus.

\section{PENDAHULUAN \\ Latar Belakang}

Perkembangan ilmu pengetahuan dan tekhnologi saat ini telah maju pesat seiring kemajuan zaman. Dalam dunia industri untuk menghasilkan suatu barang dibutuhkan perangkat alat yang mampu meningkatkan proses produksi dengan sistem terkontrol, begitupun pada proses pemisahan barang yang didasarkan pada kriteria tertentu sesuai yang dibutuhkan.

Pada prototype system pemisah barang yang dikontrol oleh PLC ini merupakan penelitian Prototipe Sistem Pemisah Barang Berdasarkan Ketinggian Berbasis PLC Omron CPM1A $30 \mathrm{l} / \mathrm{O}$, dimana pada penelitian tersebut hanya sampai pada tahap pembuatan dan pengujian alat agar dapat bekerja secara manual dan otomatis, dengan hasil kesimpulan; 1. Telah dibuat sebuah Prototipe
Sistem Pemisah Barang Berdasarkan Ketinggian Berbasis PLC dengan memanfaatkan PLC Omron CPM1A 30 I/O, 2. Penggunaan modifikasi sensor cahaya pada Prototipe Sistem Pemisah Barang Berdasarkan Ketinggian Berbasis PLC ini sebagai pendeteksi adanya barang yang menghalangi cukup efektif yang membuktikan dengan kemampuan sensor dalam menghidupkan sebuah lampu indicator yang terpasang pada sensor tersebut dimana menandakan terdapat barang yang terdeteksi, 3. Motor DC 12 Volt dapar diatur arah putarannya yaitu searah jarum jam atau berlawanan arah jarum jam dengan cara membalik polaritas pada sumber tegangan, 4 . Dari segi keuntungan didalam instalasi control lebih berkualitas menggunakan PLC dari pada dengan cara konvensional. (Hidayat, 2010) 
Berdasarkan hasil penelitian terdahulu belum ada analisis kinerja prototype system alat tersebut terhadap beban yang mampu dilewatkan, Sehingga penulis akan melakukan penelitian untuk menganalisis pembebanan prototype system barang berdasarkan ketinggian tersebut untuk mengetahui range kinerja.

Pada prototype system pemisah barang yang dikontrol dengan PLC untuk menganalisis pembebanan prototype system barang berdasarkan ketinggian digunakan untuk menentukan range kinerja arus terhadap beban yang variatif.

\section{Rumusan Masalah}

Sebagaimana permasalahan yang telah dikemukakan, maka terdapat dua buah permasalahan dapat dirumuskan.

1. Bagaimana pengaruh data pembebanan terhadap unjuk kerja konveyor motor dc 12 volt pada prototype system pemisah barang.

2. Bagaimana hasil analisa arus dari data pembebanan terhadap unjuk kerja konveyor motor dc 12 volt pada prototype system pemisah barang.

\section{Manfaat Penelitian}

Penelitian ini diharapkan memberikan manfaat yang positif untuk berbagai bidang.

a. Dapat menambah informasi dan referensi bacaan, sehingga dapat meningkatkan pengetahuan tentang pembebanan motor dc 12 Volt tipe EG-530AD-2F.

b. Sebagai masukan yang berguna terutama meminimalisir kesalahan pengukuran, kesalahan pembacaan dan kesalahan pencatatan data praktikum sehingga pelaksanaan praktikum dapat berjalan sesuai dengan yang diharapkan.

\section{TINJAUAN PUSTAKA}

Pada prototype system pemisah barang berdasarkan ketinggian, penelitian yang dilakukan adalah memisahkan obyek produksi yang memiliki ketinggian $5 \mathrm{~cm}$ dan 2 $\mathrm{cm}$, dilanjutkan dengan melakukan analisis beban yang boleh melewati konveyor pada prototype sehingga diketahui range kinerja prototype system pemisah barang berdasarkan ketinggian tersebut. Didapatkan bahwa beban ideal yang mampu dilewatkan pada masing-masing konveyor adalah beban mulai dari 10-120 gr (Arifin, 2013).

Proses pemisahan pada dasarnya merupakan proses penentuan pilihan untuk dipisah. Pilihan ini dapat berupa pilihan untuk menentukan baik tidaknya suatu obyek produksi, maupun pemilihan obyek produksi berdasarkan kriteria tertentu. Proses pemisahan suatu obyek produksi dalam hal ini barang yang memiliki ketinggian yang berbeda, dibutuhkan system kendali yang akurat untuk menunjang proses produksi. Pada prototype system pemisah barang berdasarkan ketinggian, penelitian ini adalah memisahkan obyek produksi yang memiliki ketinggian kurang dari $5 \mathrm{~cm}$ dan lebih dari sama dengan $5 \mathrm{~cm}$. Artinya pemisahan ini hanya digunakan untuk memisahkan antara barang yang memiliki ketinggian lebih dari sama dengan $5 \mathrm{~cm}$ atau kurang dari $5 \mathrm{~cm}$. (Hidayat,2010)

Dalam perhitungan data, kinerja dari prototype ini menggunakan hukum-hukum listrik yang ada, dan kinerja prototype ini yang utama didukung oleh motor DC sebagai penggerak konveyor, sensor sebagai pendeteksi barang, dan PLC sebagai basis kontrol.

Pada penelitian ini melakukan pengujian data arus dan pembebanan terhadap unjuk kerja konveyor motor dc 12volt eg-530ad-2f, sehingga didapatkan data hubungan antara arus dan pembebanan terhadap kinerja konveyor pada prototype system pemisah barang berdasarkan ketinggian ini.

\section{Landasan Teori}

Pada bagian ini akan dibahas mengenai teori yang mendasari penelitian ini. Terdiri dari Hukum Listrik, yang meliputi Hukum Ohm dan Hukum Kirchoff, prototype system pemisah barang berdasarkan ketinggian, yang meliputi desain penyusun prototype dan prinsip kerja prototype, metode statistic.

Catu tegangan dc dari baterai menuju ke lilitan melalui sikat yang menyentuh komutator, dua segmen yang terhubung dengan dua ujung lilitan. Kumparan satu lilitan pada gambar di atas disebut angker dinamo. Angker dinamo adalah sebutan untuk komponen yang berputar di antara medan magnet.

\section{Hukum OHM}

Sejarah Hukum Ohm ditemukan oleh Fisikawan Jerman George Simon Ohm (17871854) yang banyak menemukan karya dalam kelistrikan terutama hubungan antara tegangan, kuat arus listrik dan hambatan. Berdasarkan hasil eksperimen yang dilakukan, di mana suatu sumber tegangan diberikan pada suatu batang tembaga dan diukur arus yang mengalir pada batang tembaga itu. Dari 
hasil pengamatan, akan terjadi hubungan antara arus dan tegangan berdasarkan persamaan (2.1).

$\mathrm{V}=\mathrm{i} \times \mathrm{R}$

Di mana $\mathrm{R}$ adalah konstanta yang merupakan tahanan dari batang tembaga. Konstanta ini memberikan hubungan yang linear antara tegangan dan arus. Satuan $R$ adalah Ohm $(\Omega)$. Hukum ini dikenal sebagai Hukum Ohm. Arus listrik didefinisikan sebagai kecepatan aliran muatan listrik. Dalam pernyataan matematis ditulis berdasarkan persamaan (2.2).

$\mathrm{i}=\mathrm{dq} / \mathrm{dt}$

Arus sebesar 1 Amper adalah aliran muatan listrik sebanyak 1 coulomb/detik. Tegangan listrik didefinisikan sebagai energi persatuan muatan listrik. Dalam pernyataan matematis ditulis berdasarkan persamaan (2.3).

$\mathrm{v}=\mathrm{dw} / \mathrm{dq}$

Berdasarkan hukum Ohm, 1 Ohm didefinisikan sebagai hambatan yang digunakan dalam suatu rangkaian yang dilewati kuat arus sebesar 1 Ampere dengan beda potensial 1 Volt. "Besarnya kuat arus (I) yang melalui konduktor antara dua titik berbanding lurus dengan beda potensial atau tegangan (V) di dua titik tersebut, dan berbanding terbalik dengan hambatan atau resistansi (R) di antara mereka". (Zuhal,2004)

Arus adalah elektron yang mengalir dari satu atom ke atom lainnya melalui penghantar dan diukur dalam ampere. Satu ampere adalah aliran arus listrik dari 6,28 x 10 pangkat 28 elektron / detik pada sebuah penghantar. Jadi, arus adalah jangkauan aliran listrik yang diukur dalam ampere atau elektron / detik. (Zuhal,2004)

Tegangan adalah suatu tekanan yang menyebabkan terjadinya aliran arus listrik pada sebuah penghantar. Biasanya tegangan tergantung pada ujung-ujung kawat penghantar. Apabila ujung-ujung penghantar tersebut dihubungkan dengan batere atau generator, maka akan terjadi tegangan. Jadi, tegangan adalah daya potensial yang tetap ada walaupun tidak ada arus. (Zuhal,2004)

Hambatan adalah penahanan atau perlawanan yang diterima oleh elektronelektron yang mengalir pada sebuah penghantar oleh molekulmolekul yang ada di dalamnya. Setiap penghantar memberikan penahanan aliran arus listrik. (Zuhal,2004) Penahanan tersebut disebabkan oleh: a. Tiap-tiap atom menahan perpindahan elektron yang terjadi pada perlawanan terhadap elektron ke arah luarnya.

b. Benturan elektron-elektron dan atom tidak terhitung pada sebuah penghantar.

Muatan 1 coulomb akan memerlukan atau melepaskan energy sebesar 1 joule dalam perjalanannya melalui tegangan 1 volt.

\section{Motor DC}

Motor listrik merupakan perangkat elektromagnetis yang mengubah energi listrik menjadi energi mekanik. Energi mekanik ini digunakan untuk memutar rotor. Motor DC memerlukan suplai tegangan yang searah pada kumparan medan untuk diubah menjadi energi mekanik. Kumparan medan pada motor dc disebut stator (bagian yang tidak berputar) dan kumparan jangkar disebut rotor (bagian yang berputar). Jika terjadi putaran pada kumparan jangkar dalam pada medan magnet, maka akan timbul tegangan (GGL) yang berubah-ubah arah pada setiap setengah putaran, sehingga merupakan tegangan bolakbalik. Prinsip kerja dari arus searah adalah membalik phasa tegangan dari gelombang yang mempunyai nilai positif dengan menggunakan komutator, dengan demikian arus yang berbalik arah dengan kumparan jangkar yang berputar dalam medan magnet. Bentuk motor paling sederhana memiliki kumparan satu lilitan yang bisa berputar bebas diantara kutub-kutub magnet permanen.

Jika arus lewat pada suatu konduktor, timbul medan magnet di sekitar konduktor. pada konduktor. Pada motor dc, daerah kumparan medan yang dialiri arus listrik akan menghasilkan medan magnet yang melingkupi kumparan jangkar dengan arah tertentu. Konversi dari energi listrik menjadi energi mekanik (motor)

maupun sebaliknya berlangsung melalui medan magnet, dengan demikian medan magnet disini selain berfungsi sebagai tempat untuk menyimpan energi, sekaligus sebagai tempat berlangsungnya proses perubahan energy Agar proses perubahan energi mekanik dapat berlangsung secara sempurna, maka tegangan sumber harus lebih besar daripada tegangan gerak yang disebabkan reaksi lawan. Dengan memberi arus pada kumparan jangkar yang dilindungi oleh medan maka menimbulkan perputaran pada motor.

Motor DC yang digunakan adalah tipe Mabuchi EG-530AD-2F. Motor tipe ini memiliki tegangan maksimum 12 volt. 

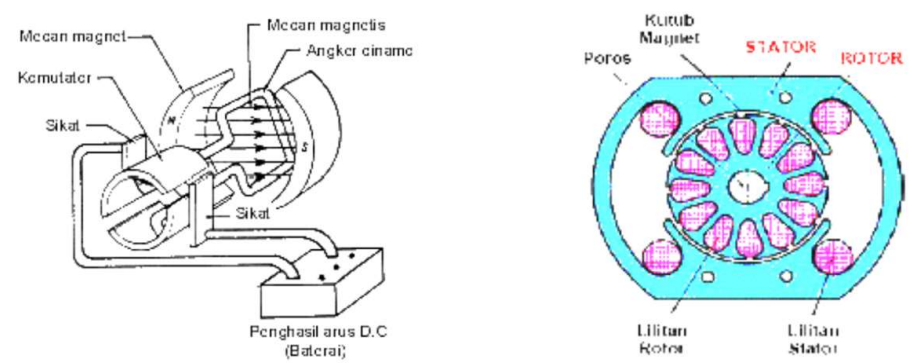

Gambar 1. Motor DC Sederhana

\section{PLC}

PLC merupakan sebuah alat yang digunakan untuk menggantikan relay yang digunakan pada pengendali konvensional. Beda PLC dan relay yaitu nomor kontak relay (NC atau NO), pada PLC dapat digunakan berkali-kali untuk semua instruksi dasar selain instruksi output. Jadi dalam suatu pemrograman PLC tidak diijinkan menggunakan alamat output dengan nomor kontak yang sama. (Eko Putra, 2004) Berdasarkan pada standar yang dikeluarkan oleh National Electrical Manufacture Association (NEMA) ICS3-1978 Part ICS3304, PLC didefinisikan sebagai berikut : "PLC adalah suatu peralatan elektronik yang bekerja secara digital, memiliki memori yang dapat diprogram menyimpan perintah-perintah untuk melakukan fungsi-fungsi khusus seperti logic, sequening, timing, counting, dan aritmatika untuk mengontrol berbagai jenis mesin atau proses melalui analog atau digital.

Sistem kontrol dengan PLC mampu mengontrol dengan daya guna dan ketelitian yang tidak dimiliki oleh sistem konvensional yang menggunakan relay elektromekanis. Relay dapat mengalami keausan dan kelelahan logam. Titik kontak pada relay dapat menimbulkan percik api yang dapat mengelasnya menjadi satu. Selain itu penempatan relay memerlukan tempat yang luas dan untuk suatu proses yang memerlukan relay banyak pada saat beroperasi penuh akan menimbulkan suara yang berisik serta panas. System relay juga memerlukan kabel untuk hubungan antar relay sehingga pada instalasi awal atau pada waktu ingin dimodifikasi membutuhkan waktu yang lama dan dapat menganggu jalannya proses. (Eko Putra, 2004)

Pada prinsipnya sebuah PLC melalui modul input bekerja menerima data-data berupa sinyal dari peralatan input luar (external input device) dari sistem yang dikontrol seperti yang diperlihatkan pada gambar diatas Peralatan input luar tersebut antara lain berupa sakelar, tombol, sensor. Data-data masukan yang masih berupa sinyal analog akan diubah oleh modul input A/D (analog to digital input module) menjadi sinyal digital. Selanjutnya oleh prosesor sentral (CPU) yang ada di dalam PLC sinyal digital itu diolah sesuai dengan program yang telah dibuat dan disimpan di dalam ingatan (memory). Seterusnya CPU akan mengambil keputusan dan memberikan perintah melalui modul output dalam bentuk sinyal digital. Kemudian oleh modul output D/A (digital to analog module) dari system yang dikontrol seperti antara lain berupa kontaktor, relay, solenoid, heater, alarm dimana nantinya dapat untuk mengoperasikan secara otomatis system proses kerja yang dikontrol tersebut. (Agfianto,2004) 


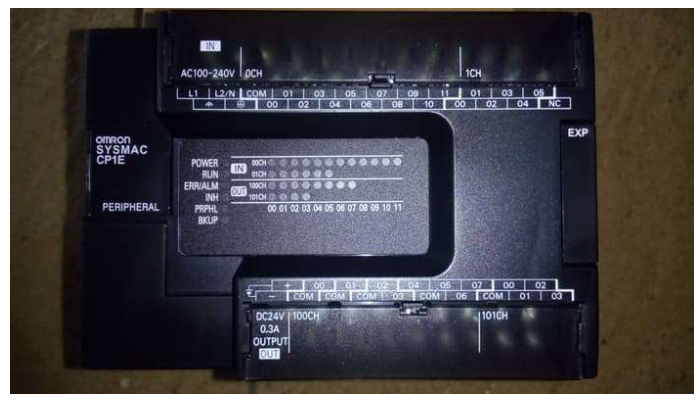

Gambar 2. PLC Omron Type CP1E

\section{HASIL DAN PEMBAHASAN}

Berdasarkan hasil pengujian arus yang dilakukan terhadap pembebanan pada beban yang bervariasi mulai dari 10 gram sampai dengan 120 gram, kelipatan beban sebesar 10 gram, dimana semakin bertambahnya beban, akan menyebabkan peningkatan arus yang dibutuhkan oleh motor untuk menggerakkan konveyor dengan membawa beban tersebut. Pengujian ini dilakukan dengan bentuk benda yang sama dengan perbedaan massa beban yang melewati konveyor. Hasil pengujian beban tersebut diperoleh data sebagaimana tabel berikut.

Tabel 1. Pengujian arus pada beban $10-120 \mathrm{gr}$

\begin{tabular}{|c|c|c|c|c|c|c|c|c|c|c|c|c|}
\hline \multicolumn{13}{|c|}{ Arus dalam Ampere DC (A) } \\
\hline \multirow{2}{*}{ Motor } & \multicolumn{12}{|c|}{ Beban dalam gram (gr) } \\
\hline & 10 & 20 & 30 & 40 & 50 & 60 & 70 & 80 & 90 & 100 & 110 & 120 \\
\hline \multirow{2}{*}{1} & 1,9 & 1,9 & 1,9 & 1,9 & 1,9 & 1,9 & 2,0 & 2,0 & 2,0 & 2,0 & 2,1 & 1,9 \\
\hline & 3 & 2 & 3 & 5 & 6 & 8 & 3 & 4 & 5 & 6 & 4 & 3 \\
\hline \multirow{2}{*}{2} & 1,9 & 1,9 & 1,9 & 1,9 & 1,9 & 1,9 & 2,0 & 2,0 & 2,0 & 2,0 & 2,1 & 1,9 \\
\hline & 3 & 2 & 3 & 5 & 6 & 8 & 3 & 4 & 5 & 6 & 4 & 3 \\
\hline \multirow{2}{*}{3} & 1,9 & 1,9 & 1,9 & 1,9 & 1,9 & 1,9 & 2,0 & 2,0 & 2,0 & 2,0 & 2,1 & 2,1 \\
\hline & 3 & 2 & 3 & 5 & 6 & 8 & 3 & 4 & 5 & 6 & 4 & 5 \\
\hline \multirow[b]{2}{*}{4} & 1,9 & 1,9 & 1,9 & 1,9 & 1,9 & 1,9 & 2,0 & 2,0 & 2,0 & 2,0 & 2,1 & 2,1 \\
\hline & 3 & 2 & 3 & 5 & 6 & 8 & 3 & 4 & 5 & 6 & 4 & 5 \\
\hline \multirow{2}{*}{5} & 1,9 & 1,9 & 1,9 & 1,9 & 1,9 & 1,9 & 2,0 & 2,0 & 2,0 & 2,0 & 2,1 & 2,1 \\
\hline & 3 & 2 & 3 & 5 & 6 & 8 & 3 & 4 & 5 & 6 & 4 & 5 \\
\hline \multirow{2}{*}{6} & 1,9 & 1,9 & 1,9 & 1,9 & 1,9 & 1,9 & 2,0 & 2,0 & 2,0 & 2,0 & 2,1 & 2,1 \\
\hline & 3 & 2 & 3 & 5 & 6 & 8 & 3 & 4 & 5 & 6 & 4 & 5 \\
\hline \multirow{2}{*}{7} & 1,9 & 1,9 & 1,9 & 1,9 & 1,9 & 1,9 & 2,0 & 2,0 & 2,0 & 2,0 & 2,1 & 2,1 \\
\hline & 3 & 2 & 3 & 5 & 6 & 8 & 3 & 4 & 5 & 6 & 4 & 5 \\
\hline un & 1.93 & 1.92 & 1.93 & 1.95 & 1.96 & 1.98 & 2.03 & 2.04 & 2.05 & 2.06 & 2.14 & 2.15 \\
\hline
\end{tabular}

Berdasarkan data pengukuran arus di atas dengan tegangan supply $12 \mathrm{Vdc} / 3 \mathrm{~A}$ diperoleh bahwa arus pada setiap motor dengan beban 10-120 gr, menunjukkan sistem bekerja pada range kerjanya, ditunjukkan data kebutuhan arus pada sistem (motor 1 sampai motor 7) dengan beban $10-120 \mathrm{gr}=2.730119$ A dengan toleransi $\pm 8.996 \%$ dari supply arus $3 \mathrm{~A}$.

Sehingga diperoleh rata-rata arus pada sistem sesuai dengan kapasitas power supply adalah sebesar $3 A \pm 8.996 \%$. 


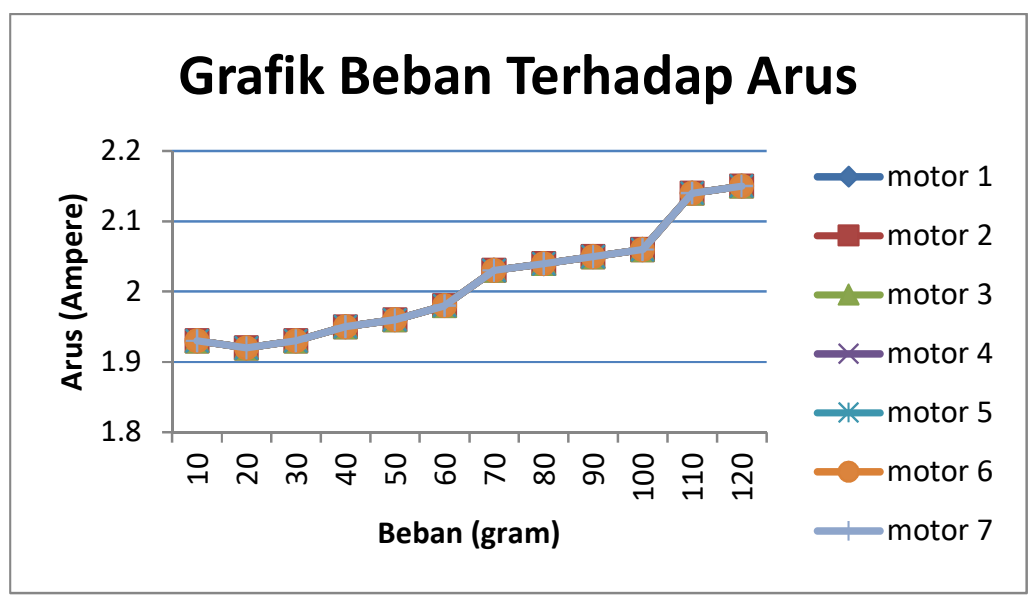

Gambar 3. Grafik peningkatan arus pada perubahan beban 10-120 gr

Sedangkan berdasarkan data pengukuran arus sesuai grafik dengan tegangan supply $12 \mathrm{Vdc} / 3 \mathrm{~A}$ diperoleh bahwa arus pada setiap motor dengan beban 10-120 gr, menunjukkan sistem bekerja pada range kerjanya, ditunjukkan data kebutuhan arus pada sistem (motor 1 sampai motor 7 ) dengan beban $10-120$ gr terjadi peningkatan nilai arus yang dibutuhkan sesuai dengan pembahan berat beban yang lewat sebagaimana hukum Ohm, bahwa semakin besar beban akan menyebabkan semakin besarnya arus yang dibutuhkan sampai dengan kapsitas maksimal arus yang digunakan.

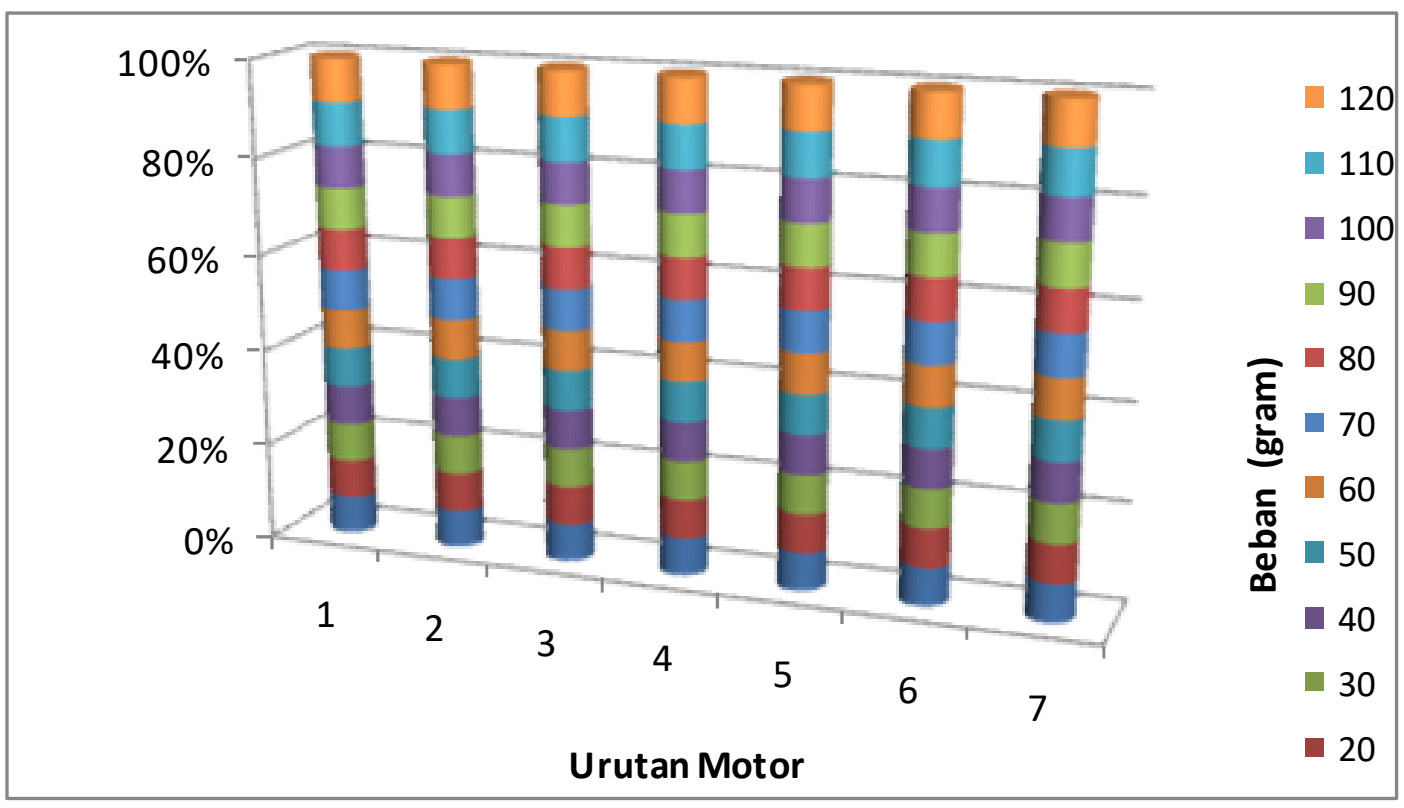

Gambar 4. Grafik kebutuhan arus motor pada perubahan beban 10-120 gr

\section{KESIMPULAN}

Berdasarkan penelitian yang dialakukan yaitu analisis pembebanan pada prototype system pemisah barang berdasarkan ketinggian berbasis PLC ini, maka dapat diambil kesimpulan sebagai berikut:
1. Beban yang mampu dilewatkan pada masing-masing motor yang difungsikan sebagai konveyor adalah beban mulai dari 10-120 gr

2. Arus yang dibutuhkan adalah sebesar $3 \mathrm{~A} \pm 8.996 \%$. 
3. Seiring dengan peningkatan berat beban, maka kebutuhan arus juga semakin meningkat, (beban dan arus memiliki hubungan sebanding).

\section{Daftar Pustaka}

Hidayat, Nurul, 2010, Laporan Proyek Akhir Prototipe Sistem Pemisah Barang Berdasarkan Ketinggian Berbasis PIC Omron Cpm1a 30 I/O, Universitas Muria Kudus, Kudus.

Arifin, Zaenal, "Analisis Pembebanan Prototipe Sistem Pemisah Barang Berdasarkan
Ketinggian." Universitas Muria Kudus, Kudus, 2013.

Zuhal, Zhanggischan, 2004, Prinsip Dasar Elektroteknik. Gramedia Pustaka Utama. Jakarta.

Budiyanto, M., A. Wijaya, 2004 Pengenalan Dasar-dasar PLC (Programmable Logic Controller), Gava Media, Yogyakarta.

Eko Putra, Agfianto, 2004, PLC Konsep, Pemrograman dan Apilkasi, Gava Media, Yogyakarta.

Wicaksono, Handy, 2012, SCADA Software dengan Wonderware Intouch Dasardasar Pemrograman, Graha IImu, Yogyakarta. 